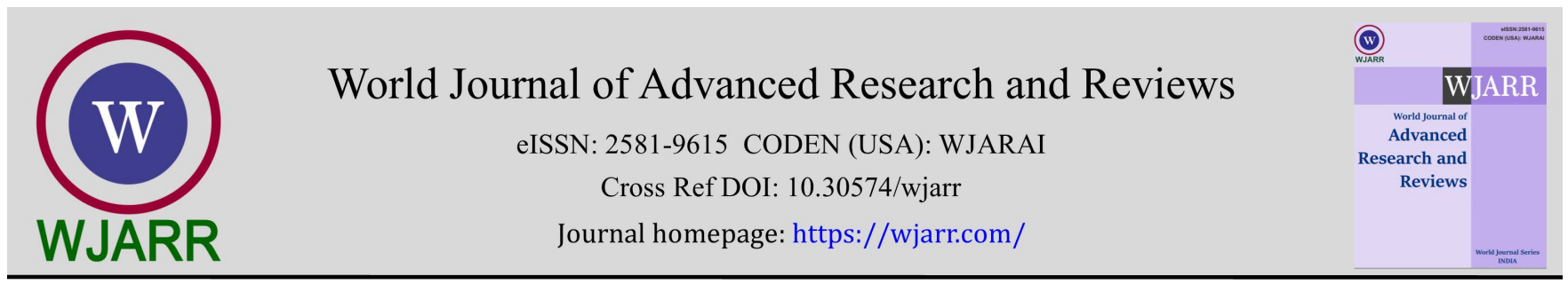

(RESEARCH ARTiClE)

\title{
Market timing of CEOs and foreign investors' reaction
}

\author{
Thu Quang Luu ${ }^{1,}{ }^{*}$, Vo Thien Trang ${ }^{1}$ and Nguyen Thi Thu Trinh ${ }^{2}$ \\ ${ }^{1}$ Banking University of Ho Chi Minh City, Vietnam. \\ 2 University of Finance and Accountancy, Vietnam.
}

World Journal of Advanced Research and Reviews, 2022, 13(02), 492-500

Publication history: Received on 11 November 2021; revised on 24 February 2022; accepted on 26 February 2022

Article DOI: https://doi.org/10.30574/wjarr.2022.13.2.0179

\begin{abstract}
Excess return, cumulative abnormal return, market to book ratios and liquidity risk are applied as proxies for evaluating the chief executive officer's (CEO) market timing. The result indicates that managers have total succeeded in timing the market for SEO events. Firms implement seasonal equity offering (SEO) issuance after experiencing a strong increase of stock price, and then underwent a significant reversal of stock price. Besides that, CEO will time the market when they realize the liquidity risk of firms drop to the point where institutional investors have low consideration about risks. Foreign investors reacted strongly when the information about the SEO was announced, specifically, they changed their trading behavior from being a net buying to being a net selling or reducing buying. This reaction is especially strong in companies with low market liquidity. And as a result, foreign investors react more quickly to the information of new stock issuance, their stock return will increase sharply after SEO.
\end{abstract}

Keywords: Return; Seasonal equity offering; Market timing; Foreign investor trading

\section{Introduction}

In recent years, the topic of research on the theory of market timing is still receiving more and more attention from scientists around the world. The theory of market timing is studied for various events including initial public offering (IPO), mergers and acquisitions (M \& A), treasury stock repurchases (SR), subsequent stock issuances, stock listings, etc. And to study the theory of market timing, scientists have used a variety of models and variables such as the use of cumulative excess returns (cumulative abnormal return), M/B ratio, market risk, liquidity risk.... However, the number of studies on this topic is mostly done in developed markets and near-term markets. In border or emerging markets where the problem of asymmetric information is still serious and mostly dominated by individual investors like Vietnam, there are very few research topics. Especially, according to the author, in Vietnam, there is only one study on this topic at present. Therefore, it is necessary to have more research topics on this topic with different methods and approaches to strengthen the theory for emerging and frontier markets. This study will provide an overview for investors in Vietnam so that they can have more neutral information to serve their investment decisions when CEOs announce information about additional shares issuance to the public. In addition, the actions of foreign investors are one of the important indicators for domestic investors, so it is necessary to have a study to examine the reaction of foreign investors to SEO market timing.

In this study, we use Data Stream datasets and hand-collected stock issuance (SEO) data to investigate whether market timing theory still holds true in an emerging market such as the stock market. Vietnamese securities. Specifically, the author uses excess return, cumulative abnormal return, and liquidity risk as tools to examine CEO in choosing the right time to issue shares. This research paper is divided into four parts, first the author introduces the reason for choosing the topic, and the second part introduces the previous studies on the theory of market timing. Followed by the third

\footnotetext{
${ }^{*}$ Corresponding author: Thu Quang Luu

Banking University of Ho Chi Minh City. Vietnam.

Copyright (C) 2022 Author(s) retain the copyright of this article. This article is published under the terms of the Creative Commons Attribution Liscense 4.0.
} 
part, the author explains in detail the research methods and proposes research models, calculation formulas and makes assumptions based on previous studies. The 4th part will present the research results, the 4 th part will include 3 small parts: testing the variables around SEO, foreign investors' transactions around SEO and testing the profits of foreign investors corresponds to their behavior at the most SEO stage. The final part is the conclusion and recommendations of the study.

\section{Literature review}

Market timing theory is based on three main assumptions, first and foremost, that controlling shareholders have more information than outside shareholders. Second, many outside shareholders cannot perceive their own disadvantage compared to the trading behavior of the controlling shareholder. Finally, outside shareholders understand that controlling shareholders are restricted from trading in securities. The market timing theory is shaped by the problem of asymmetric information. Specifically, managers (CEOs) will have more information about the business than outside shareholders, so when they think that the market is valuing the company above its true value, they will tend to issue shares new shares (Seasonal equity offering) to the public in order to maximize the benefits of existing shareholders or increase capital surplus. Usually new issues of shares will take place after a long stock price up cycle and after the company completes the issue of new shares, the stock price will tend to go down [1]. Armen [2] also found evidence that market-book valuation $(\mathrm{B} / \mathrm{M})$ ratios tend to increase before the company issues shares and will decrease after the company completes the issue of shares.

To answer the question of whether the company chooses the time to issue equity to benefit existing shareholders? Armen [2] classified foreign investors into short-term and long-term based on their average portfolio over the last four quarters to examine the difference between long-term and short-term foreign shareholders when the company issues new shares. The results show that companies with a larger percentage of foreign ownership are less likely to exercise time selection to issue shares, and long-term investors will enjoy more benefits than short-term shareholders when the company chooses when to issue new shares.

Lin's study [3] looks at another aspect of market timing theory when he focuses on liquidity risk. Specifically, Lin [3] discusses that companies intend to issue new shares when they believe that liquidity risk is reduced to the point where investors (who are willing to buy new shares) have no or little worry about the risk. Therefore, CEOs have chosen the time when the market sells stocks at high prices or when the liquidity risk is lowest in order to attract more attention from foreign investors.

Another research group [4],[5],[6] investigated the ability of foreign investors to time the market rather than CEOs of the enterprise. These studies show that foreign investors often have better trading results due to their experience. And mutual funds have demonstrated the ability to accurately time the market or in other words have successfully sold stocks at a high price before it drops in price.

In another aspect, when looking for a link between SEO and foreign ownership rate. Gibson et al [7] examined quarterly data on foreign ownership, and found that firms that perform SEO experience the highest growth around the disclosure period. Foreign investors can identify SEO businesses with above-average growth rates in the market to increase their ownership rate in these potential companies. In contrast, Borja and Francisco [8] show that stock issuances are usually made when the business has a low growth rate, which significantly reduces the attractiveness of the issue, thereby reducing the interest by foreign shareholders. Armen and Huajing [2] agree that existing foreign investors tend to increase their share ownership at the time of SEO, including undervalued and overvalued stocks. Another special thing is that Armen and Huajing [2] find that the higher the percentage of foreign ownership, the less incentive for CEOs to take action to time the market. Thomas et al [9] are the pioneers in studying the role of foreign investors in the public offering of shares. They deduced that foreign investors with inside information in share offerings would act as producers of information rather than using it to manipulate prices.

Based on what the author has explored in previous studies and theories, this study of the authors will have three main contributions: This is the first study to exploit daily trading data of foreign investors to test how they react to stock issuance events to exploit the CEO's informational advantage. All studies in the past have often used quarterly or annual data on foreign investors' transactions. Using quarterly or annual data can lead to bias issues because changes in foreign investor behavior occur almost immediately after SEO information becomes available, so quarterly data or year will not reflect timely. We are the first to use the daily transaction data of foreign investors to investigate their movements around SEO events. 
Although there are many different studies on market timing theory, most of them focus on studying the relationship between SEO timing action and foreign ownership [10]. The second contribution of this study is the first study to investigate the perceived ability of foreign investors to the choice of time to issue shares of CEOs. In addition, we also investigate the return of foreign investors for the period after the company implements SEO to find out what is the relationship between the return and the response of foreign investors in the period of SEO events.

\section{Data and methodology}

\subsection{Data}

Data on Vietnamese companies was collected for the period from January 1, 2005 to December 31, 2020. Data on adjusted share prices, trading volumes, as well as new issues of shares are collected by the author manually and from the Thomson Reuter and FinnPro datasets. These are two highly reliable datasets that are widely used in research for emerging markets and many studies based on this dataset have been published in leading scientific journals. According to information from Data Thomson Reuters, a total of more than 1700 companies listed on the Vietnam stock exchange have successfully conducted 665 new stock issuances. In this study, we exclude financial companies from the general sample, in addition, companies that have issued shares but lack the necessary data for analysis are also excluded from the general sample. After this process is done, there is a sample of 515 new stock issuances of 381 companies listed on the Vietnam Stock Exchange.

As discussed above, previous studies have shown that companies tend to issue shares after experiencing a sharp increase in excess returns, and the excess returns tend to reverse downward after the issue is completed [11]. The excess return is calculated by subtracting the stock return of the issuer from the market return, VNINDEX is used as the market index return for companies. The company is listed on the Vietnam Stock Exchange. Because different companies will have different issue dates, we calculate the average excess return (ER) for different time frames using the following formula:

$$
\operatorname{ER}(T 1, T 2)=\frac{\sum_{T 1}^{T 2}\left(R_{i t}-R_{M t}\right)}{T 2-T 1+1}
$$

Where

- $\mathrm{T} 1$ is the start date of the timeframe

- $\quad \mathrm{T} 2$ is the end date of the timeframe

- $\mathrm{R}_{\mathrm{it}}$ is the daily return of stock $i$ for day $t$

- $\mathrm{R}_{\mathrm{Mt}}$ is the market return of day $t$

Based on previous studies, we have the first hypothesis: H1. Companies that issue new shares will experience positive returns before the issue is made, and negative excess returns after the issue is made.

Second, because foreign investors operate on the principle of prudence, they pay much attention to risk management, so to attract foreign investors to buy their shares, CEOs must choose a time when the company's risks (including liquidity risk and market risk) are low in order to attract this group of investors. The market timing theory of Lin and $\mathrm{Wu}$ [3] argues that: in markets with time-varying risk, firms will choose to issue shares when market risk /lowest liquidity to attract foreign investors. Following the above idea, we make a second hypothesis: H2. Market risk and liquidity risk of companies will experience a decline before the issuance is made and will reverse to increase after the issuance is made

To estimate market risk/liquidity risk to test the hypothesis, we apply Ibbotson's [12] RATS regression technique. Specifically, we run the following cross-regression model:

$$
\text { rit }-\mathrm{rft}=\alpha \mathrm{t}+\beta \mathrm{m}, \mathrm{t}(\mathrm{rmt}, \mathrm{i}-\mathrm{rft}, \mathrm{i})+\beta \mathrm{l}, \mathrm{tLIQt}, \mathrm{i}+\varepsilon \text { it for } \mathrm{i}=1,2, \ldots, \mathrm{n} \ldots \ldots \ldots
$$

Where

- $\quad r_{i t}$ is the excess return of company i month $t$

- $\mathrm{r}_{\mathrm{ft}}$ is the risk-free rate of month $t$

- $r_{m t, i}$ is the market return of month $t$ 
- $\quad \mathrm{LIQ}_{\mathrm{t}, \mathrm{i}}$ is the monthly market liquidity premium of company $\mathrm{i}$

LIQ is built based on the research of Liu [13], LIQ is the difference return between the portfolio of low liquidity stocks (containing stocks with low LM12) and the portfolio of highly liquid stocks (containing stocks with high LM12). The construction of the LIQ variable is similar to the SMB variable (small minus big) and the HML variable (high minus low). After running the above regression model, we will find $\beta_{\mathrm{m}, \mathrm{t}}$ and $\beta_{\mathrm{l}, \mathrm{t}}$, which is the market risk and liquidity risk for month t.

$$
L M 12=\left[\text { number of trading day equal zero }+\frac{1}{10.000}\right] \times \frac{21 \times 12}{\text { Number of trading days }}
$$

After answering the question of whether CEOs are successful in choosing the right market time to issue shares to maximize benefits for the company and attract investors, we will find out by seeing foreign investors' trading reactions before and after the information about the issuance is announced. We use the method of Griffin [14] and Hung [15] to calculate the net foreign trading imbalance (FTI) per share of SEO issue i on trading day $t$ as after:

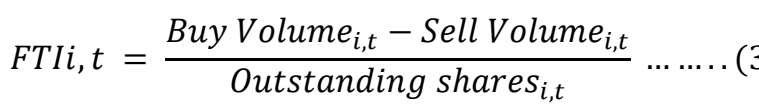

In which, we use Buy Volume $e_{i, t}$ is the buying volume of foreign investors for stocks performing SEO i on trading day $t$. Sell Volume $e_{i, t}$ is the selling volume of foreign investors for stocks performing SEO i on trading day t. And Outstanding share $_{i, t}$ is the number of outstanding shares of company $i$ at time t. Positive FTI i.e. more shares are bought by foreign investors than are sold, indicating that foreign ownership is increasing in that stock. Conversely, a negative FTI means that foreign investors are selling more than buying. FTI is used to check the trading trend of foreign investors around the time when the company implements SEO.

To measure the changes in foreign investors' trading behavior when the SEO announcement comes out, we use the cumulative net foreign trading imbalance (CFTI) for the various time. Specifically, we observe CFTI for the pre-event and post-event timeframes to estimate the degree of inversion in the trading behavior of foreign investors, the Inverse Indicator (II) is calculated as:

$$
I I_{i, T}=\operatorname{CFTI}_{i,(+3,+T)}-C F T I_{i,(-3,-T)}
$$

In which, $\mathrm{II}_{\mathrm{i}, \mathrm{T}}$ represents the inverse indicator in transactions of foreign investors for the event of company $i$ at time frames $T$

\section{Results and discussion}

\subsection{Market timing of CEO}

Table 1 presents the mean and median of excess returns associated with the respective statistical test results. Panel a of Table 1 shows issuers that experienced significant negative average excess returns in the one-month period prior to the release date, as well as the average positive excess return for the 2 month period after the announcement. This result is not consistent with our initial hypothesis H1. But when looking at the issue date in Panel B of Table 1, the results show that the company experienced a period of positive excess returns before issuing shares (specifically, the average ER of the time frame). And these companies have negative average excess returns after 5 days and 1 month of stock issuance, specifically ER (issue date +1 , issue date +5 ) and ER (issue date +1 ). , issue month +1 ) are -1.89 and -0.89 respectively, all statistically significant. 
Table 1 The excess return (ER) of the stock during the new issue of shares. ER is measured by cumulative marketadjusted returns for specific timeframes calculated in days. "Announcement date $-\mathrm{t}$ " means $t$ days prior to the release event; "announcement date $+\mathrm{t}$ " means $t$ days after the release date of the release

\begin{tabular}{|c|c|c|c|}
\hline & Mean & Median & Observation \\
\hline \multicolumn{4}{|l|}{ Panel A: Around SEO announcement } \\
\hline \multicolumn{4}{|l|}{ Pre-announcement } \\
\hline ER (announcement date -5 , announcement date -1 ) & -1.18 & $-4.59^{* *}$ & 431 \\
\hline ER (announcement date -2 , announcement date -1) & -1.48 & $-3.59^{*}$ & 431 \\
\hline ER (announcement month -1 , announcement month 0 ) & $-3.64^{* * *}$ & $-3.87^{*}$ & 431 \\
\hline ER (announcement month -3 , announcement month 0 ) & $-2.95^{* * *}$ & $-4.02^{* *}$ & 431 \\
\hline \multicolumn{4}{|l|}{ Post-announcement } \\
\hline ER (announcement date 0 , announcement date +1 ) & 3.55 & $2.27^{* *}$ & 431 \\
\hline ER (announcement date 0 , announcement date +5 ) & 2.68 & -0.03 & 431 \\
\hline ER (announcement date 0 , announcement date +2 ) & $1.78^{* * *}$ & $0.03^{*}$ & 431 \\
\hline \multicolumn{4}{|l|}{ Panel B: Around SEO Issuance } \\
\hline \multicolumn{4}{|l|}{ Pre-issuance } \\
\hline ER (issuance date -5 , issuance date -1 ) & $2.08^{*}$ & -0.94 & 515 \\
\hline ER (issuance date -2 , issuance date -1 ) & 2.85 & $-0.96^{*}$ & 515 \\
\hline ER (issuance month -1 , issuance month 0 ) & -0.66 & $-0.72^{*}$ & 515 \\
\hline \multicolumn{4}{|l|}{ Post-issuance } \\
\hline ER (issuance date 0 , issuance date +1 ) & -1.28 & $-2.08^{* *}$ & 515 \\
\hline ER (issuance date +1 , issuance date +5 ) & $-1.89^{*}$ & $-1.98^{* *}$ & 515 \\
\hline ER (issuance month +1 , issuance month +1 ) & $-0.89^{*}$ & $-0.17^{*}$ & 515 \\
\hline
\end{tabular}

Table 2 Summary regression results for 36 months before and 36 months after the company issues new shares. Applying regression technique to Lin's model (2013): $r_{i t}-r_{f t}=\alpha_{t}+\beta_{m, t}\left(r_{m t, i}-r_{f t, i}\right)+\beta_{l, t} L_{I} Q_{t, I}+\varepsilon_{i t}$ cho $i=1,2, \ldots, n$ companies in each month have $t$ share issuance events in the period 36 months before and 36 months after the company issues new shares. $\beta \mathrm{m}, \mathrm{t}$ and $\beta \mathrm{l}, \mathrm{t}$ are market risk and liquidity risk. The variables have been explained in the research methods section

\begin{tabular}{|l|l|l|l|l|l|l|l|l|l|l|l|}
\hline Month & $\mathbf{- 3 6}$ & $\mathbf{- 2 4}$ & $\mathbf{- 1 2}$ & $\mathbf{- 6}$ & $\mathbf{- 1}$ & $\mathbf{0}$ & $\mathbf{+ 1}$ & $\mathbf{+ 6}$ & $\mathbf{+ 1 2}$ & $\mathbf{+ 2 4}$ & $\mathbf{+ 3 6}$ \\
\hline$\alpha_{\mathrm{t}}$ & 2.32 & 1.23 & 4.32 & 2.90 & 3.28 & 2.27 & 1.56 & 5.32 & 1.43 & 2.33 & 4.31 \\
\hline$\beta \mathrm{l}, \mathrm{t}$ & -0.134 & -0.292 & -0.415 & -0.354 & -0.241 & -0.228 & -0.441 & -0.431 & -0.521 & -0.442 & -0.454 \\
\hline$\beta \mathrm{m}, \mathrm{t}$ & 1.143 & 0.905 & 0.915 & 1.002 & 0.541 & 0.454 & 0.526 & 0.592 & 0.821 & 0.790 & 0.918 \\
\hline $\mathrm{R} 2$ & 0.33 & 0.24 & 0.43 & 0.11 & 0.24 & 0.17 & 0.32 & 0.28 & 0.21 & 0.19 & 0.12 \\
\hline
\end{tabular}

Foreign investors normally follow the rules of caution and limit risks. Based on that perspective, Lin [3] hypothesizes that companies tend to issue new shares when the liquidity risk of company's decreases to a level that investors are willing to accept that share. In this section we will observe in more detail the market risk and liquidity risk of companies 
before 36 months and after 36 months when companies issue new shares. To find the liquidity risk and market risk of companies for the period from -36 to +36 months we have to do a total of 73 regressions of formula (2) by month.

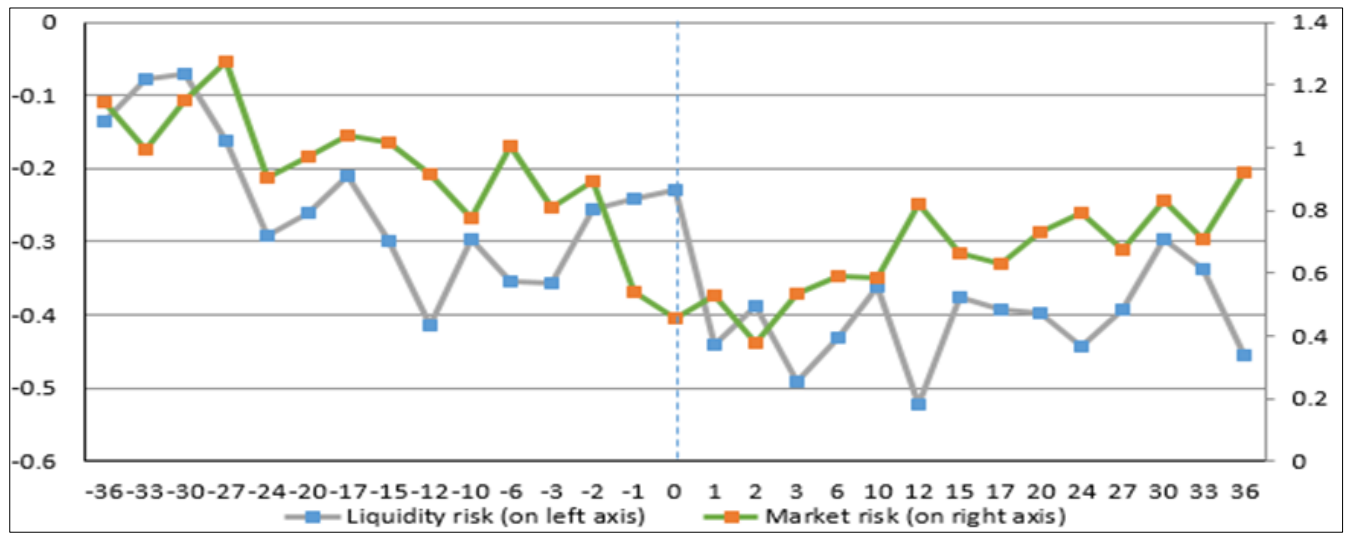

Figure 1 Illustrate the market risk and liquidity risk of companies surrounding the new issue of shares. The blue line represents market risk, the gray line showing liquidity risk

Table 2 and Figure 1 show that about 12 months before issuing new shares, liquidity risk tends to increase, and liquidity risk decreases sharply after issuing new shares. This result is opposite with hypothesis H2. However, if we look at a longer period of time, 36 months before the issuance, we see that liquidity risk has steadily decreased so assuming $\mathrm{H} 2$ is correct in the first part. Meanwhile, the market risk clearly goes down and bottoms when the company issues new shares, then increases continuously up to 36 months after the time of issuance. Thus, hypothesis $\mathrm{H} 2$ has been confirmed, the evidence shows that when managers realize that the market risk has fallen to a bottom, they quickly apply for a new issue of shares to attract public participation to buy their shares.

\subsection{Foreign investors' transactions around SEO events}

Table 3 shows the average net trading imbalance of foreign investors around the SEO event, $t=0$ is the date of the SEO announcement, $\mathrm{t}=-10$ is 10 days before the SEO announcement event, $\mathrm{t}=10$ is 10 days after the announcement of the SEO event. The results show that before the announcement date, the average transaction of foreign investors is a net buy for both time frames $(-10,-30$ and $(-5,0)$ days. But after the announcement of the SEO round, we see that the trading behavior of foreign investors has changed from being a net buy to a net selling, specifically Ave $(+3,+10)$ and Ave $(0,+5)$ were negative. In Table 3 we take the average transaction of foreign investors of the time frame after SEO minus the average transaction of foreign investors before SEO to get the mean difference. This is a measure of the difference in trading before and after SEO and this indicator is negative and statistically significant for both time frames, which proves there is a clear change in trading behavior of foreign investors after receiving SEO information, either they switch from net buy to net sell or they are from buying a lot to reducing buying.

Table 3 Foreign trade imbalance (FTI) around SEO events (\%). Mean difference-1 = Ave $(+3,+10)-$ Ave $(-10,-3)$; mean difference- $2=$ Ave $(0,+5)$-Ave $(-5,0)$. All value in percentage

Panel A: Market adjusted
\begin{tabular}{|l|l|l|c|l|l|c|}
\hline & Ave(-10,-3) & Ave(+3,+10) & Mean difference-1 & Ave(-5,0) & Ave(0,+5) & Mean difference-2 \\
\hline FTI & $0.0046(4.24)$ & $-0.0043(-3.22)$ & $-0.0089(-2.02)$ & $0.0057(4.31)$ & $-0.0065(-3.62)$ & $-0.0122(-2.83)$ \\
\hline \multicolumn{7}{|l|}{ Panel B: Industry adjusted } \\
\hline & Ave(-10,-3) & Ave(+3,+10) & Mean difference-1 & Ave(-5,0) & Ave(0,+5) & Mean difference-2 \\
\hline FTI & $0.0021(3.08)$ & $-0.0068(-4.04)$ & $-0.0090(-2.95)$ & $0.0041(3.98)$ & $-0.0093(-4.55)$ & $-0.0134(-3.22)$ \\
\hline
\end{tabular}




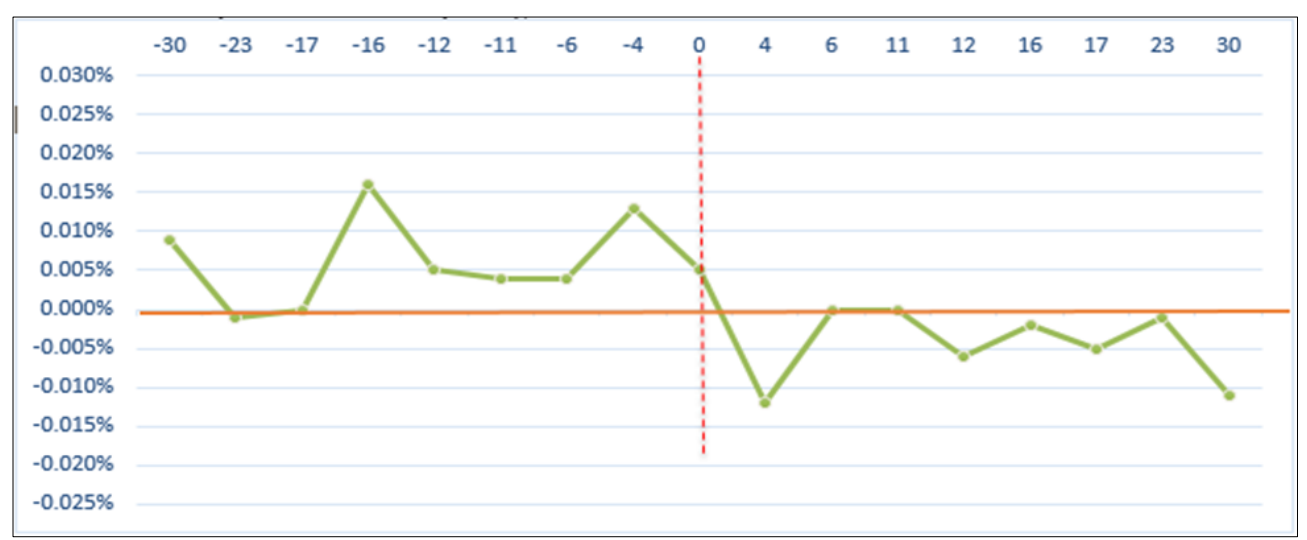

Figure 2 Illustrate daily net foreign trading imbalance (FTI) around SEO events

\subsection{The relationship between the change in foreign investors' trading and stock returns}

Next, we examine the relationship between the inverse of cumulative abnormal returns (DIFt) and other control variables such as BM, MV and inverse indicator in foreign investors' trading (II). The dependent variable (DIFt) is measured as a cumulative abnormal return change before the SEO event and after the SEO event, calculate DIFt $=$ CAR $(+3,+\mathrm{T})$ - CAR $(-\mathrm{T},-3)$, where $\mathrm{T}$ takes the values 10,20 , and 30 respectively. Table 4 , panel $\mathrm{B}$ shows that the inverse of cumulative abnormal returns is significantly and positively related to the BM index but inversely related to market capitalization. For stocks with low trading liquidity, we see higher BM and smaller market caps earn higher inverse returns in the post-SEO period. Table 4 also shows that the inverse indices are all statistically significant, and that the $\mathrm{II}_{\mathrm{i}}$ increases over time corresponding to $\mathrm{DIFt}=10,20,20$. That is, the more inverse transactions, the more foreign investors create a higher return inverse in the future, it supports hypothesis that foreign investors are correct in identifying the market timing of CEOs.

Table 4 Regression of $D I F_{t}$ around SEO events for various timeframe. Dependent variable: $D I F_{t}=\mathrm{CAR}(+3,+\mathrm{T})-\mathrm{CAR}$ $(-\mathrm{T},-3)$, in which $\mathrm{T}$ take value $=10,20,30$ days. Independent variable $I I_{i, t}$ is inverse indicator of foreign investor. All firms are divided into 3 sub-sample based on liquidity. Other independent variables are explained in Appendix. T-ratios is in parenthesis

\section{Panel A: All firms}

\begin{tabular}{|c|c|c|c|c|c|c|c|c|c|}
\hline & Intercept & $\log (\mathrm{BM})$ & $\log (\mathrm{MV})$ & II $_{\mathrm{FI}, \mathrm{t}}$ & Industry dummy & Year dummy & Obs & Adj. R ${ }^{2}$ & F-statistics \\
\hline $\mathrm{DIF}_{\mathrm{t}=10}$ & $0-9.438(-0.79)$ & $-0.245(-0.21)$ & $-0.270(-0.55)$ & $2.844(5.23)$ & Yes & Yes & 431 & 0.136 & 1.93 \\
\hline $\mathrm{DIF}_{\mathrm{t}=20}$ & $0.0 .403(-0.02)$ & $-0.959(-0.51)$ & $-1.055(-1.31)$ & $3.525(4.06)$ & Yes & Yes & 431 & 0.047 & 1.29 \\
\hline $\mathrm{DIF}_{\mathrm{t}=30}$ & $0-16.06(-0.71)$ & $0.669(0.31)$ & $-0.085(-0.09)$ & $5.105(5.12)$ & Yes & Yes & 431 & 0.119 & 1.80 \\
\hline
\end{tabular}

\section{Panel B: Firm with low liquidity}

\begin{tabular}{|c|c|c|c|c|c|c|c|c|c|}
\hline & Intercept & $\log (\mathrm{BM})$ & $\log (M V)$ & $\mathbf{I I}_{\mathrm{FI}, \mathrm{t}}$ & Industry dummy & Year dummy & Obs & Adj.R2 & F-statistics \\
\hline $\mathrm{DIF}_{\mathrm{t}=10}$ & $6.933(0.62)$ & $1.211(0.85)$ & $-1.290(-2.34)$ & $2.694(4.02)$ & Yes & Yes & 215 & 0.185 & 1.75 \\
\hline $\mathrm{DIF}_{\mathrm{t}=20}$ & $19.64(0.98)$ & $3.627(1.40)$ & $-2.532(-2.52)$ & $3.622(3.20)$ & Yes & Yes & 215 & 0.076 & 1.27 \\
\hline $\mathrm{DIF}_{\mathrm{t}=30}$ & $-1.341(-0.06)$ & 6.098 (2.39) & $-0.972(-0.97)$ & $5.507(4.94)$ & Yes & Yes & 215 & 0.200 & 1.83 \\
\hline
\end{tabular}

Panel C: Firm with high liquidity

\begin{tabular}{|c|c|c|c|c|c|c|c|c|c|}
\hline & Intercept & $\log (\mathrm{BM})$ & $\log (\mathrm{MV})$ & II $_{\mathbf{F I}, \mathrm{t}}$ & Industry dummy & Year dummy & Obs & Adj. $R^{2}$ & F-statistics \\
\hline $\mathrm{DIF}_{\mathrm{t}=10}$ & $0-10.69(-0.86)$ & $-2.683(-1.27)$ & $1.234(1.30)$ & $3.659(3.83)$ & Yes & Yes & 216 & 0.120 & 1.45 \\
\hline $\mathrm{DIF}_{\mathrm{t}=20}$ & $-9.682(-0.48)$ & $-7.938(-2.36)$ & $1.134(0.75)$ & $4.485(3.08)$ & Yes & Yes & 216 & 0.003 & 1.00 \\
\hline $\mathrm{DIF}_{\mathrm{t}=30}$ & $0-31.90(-1.33)$ & $-7.301(-1.81)$ & $1.384(0.76)$ & $5.961(3.29)$ & Yes & Yes & 216 & 0.047 & 1.16 \\
\hline
\end{tabular}




\section{Appendix}

\begin{tabular}{|c|c|}
\hline FI & Foreign investor \\
\hline DIF & $\mathrm{DIF}=\mathrm{CAR}_{(+3,+\mathrm{T})}-\mathrm{CAR}_{(-\mathrm{T},-3)}$, in which $\mathrm{T}$ take value $=10,20,30$ \\
\hline $\mathrm{FTI}_{(-\mathrm{B},+\mathrm{T})}$ & $\begin{array}{l}\text { Foreign investor trading imbalance. }-\mathrm{B} \text { is the } \mathrm{B} \text { date before SEO, } 0 \text { is announcement date, and }+\mathrm{T} \text { is the } \\
\mathrm{T} \text { date after SEO }\end{array}$ \\
\hline $\mathrm{II}_{\mathrm{i}, \mathrm{T}}$ & Inverse indicatior II $=\operatorname{CATD}_{(+3,+\mathrm{T})}-\mathrm{CATD}_{(-\mathrm{T},-3)}$, In which $\mathrm{T}$ take value $=10,20,30$ \\
\hline BM & Book value \\
\hline MV & Maket value \\
\hline $\operatorname{CAR}_{(-H,+T)}$ & $\begin{array}{l}\text { Cumulative abnormal return for timeframe }(-\mathrm{H},+\mathrm{T}) \text {, in which }-\mathrm{H} \text { is the } \mathrm{H} \text { day before SEO, } 0 \text { is } \\
\text { announcement date, }+\mathrm{T} \text { is the } \mathrm{T} \text { day after SEO announcement. }\end{array}$ \\
\hline
\end{tabular}

\section{Conclusion}

By using the excess return and the liquidity method of Liu [13], we come to the conclusion that the CEOs have been very successful in choosing the right time to issue equity to maximize company profits. Specifically, when the company is overvalued by the market, they will tend to issue new shares, after each new issue of shares, the share price will tend to decrease for a long time. In addition, market risk is also a factor that makes CEOs decide to issue shares, specifically they will choose the lowest market risk time to issue new shares to attract foreign investors because these investors operate on the principle of prudence. The research results also show that foreign investors are not aware of the stock issuance in advance (insider information) but they have realized that every time the CEO makes a share issue, the CEO will choose the time when the market values the highest shares to issue to exploit the advantages of existing shareholders, after the issuance, the share price will start to go down. Therefore, foreign investors reacted strongly when the information about the SEO was announced, specifically, they changed their trading behavior from being a net buying to being a net selling or reducing buying. This reaction is especially strong in companies with low market liquidity. And as a result, foreign investors react more quickly to the information of new stock issuance, their stock return will increase sharply after SEO.

\section{Recommendations}

In general, the stock price will undergo a period of steady increase and peak at the time the company announces the new share issuance, then the price will gradually decrease, this result is similar to most of the researches in other countries around the world. Therefore, from the perspective of an investor in the Vietnamese market, this study recommends that investors consider selling stocks when the stock market rises sharply and companies rush to announce issue new shares.

\section{Compliance with ethical standards}

\section{Acknowledgments}

This study would not have been possible without the support from my university, Banking University of Hochiminh, my colleagues, Vo Thien Trang, Nguyen Thi Thu Trinh.

\section{Disclosure of conflict of interest}

There is no conflict of interest in this research.

\section{Statement of ethical approval}

Research ethical issues were addressed carefully on this study.

\section{Statement of informed consent}

Informed consent was obtained from all individual participants included in the study. 


\section{References}

[1] Stephens C, Weisbach W. Actual share reacquisitions in open-market repurchase programs. Journal of Finance. 2000; 53: 313-334.

[2] Armen H, Huajing H. Institutional shareholders and SEO market timing. Journal of Corporate Finance. 2016; 36: $1-14$.

[3] Lin J, Wu Y. SEO timing and liquidity risk. Journal of Corporate Finance. 2013; 19: 95-118.

[4] Grinblatt M, Keloharju M. The investment behavior and performance of various investor types: a study of Finland's unique data set. Journal of Finance. 2000; 51: 589-616.

[5] Froot K, Ramadorai T. Institutional Portfolio Flows and International Investments. Review of Financial Studies. 2008; 21(2): 937-971.

[6] Li L, Xueyong Z, Yeqing Z. Mutual fund managers' timing abilities. Pacific-Basin Finance Journal. 2017; 44: 80-96.

[7] Gibsond S, Safieddine A, Sonti R. Smart investments by smart money: evidence from seasoned equity offerings. Journal Financial Economic. 2004; 72: 581-604.

[8] Borja L, Francisco Urzúa I. Controlling shareholders and market timing in share issuance. Journal of Financial Economics. 2013; 109: 661-681.

[9] Thomas JC, Shan H, Gang H. The role of institutional investors in seasoned equity offerings. Journal of Financial Economics. 2009; 94: 384-411.

[10] Omar AE. Controlling shareholders and market timing: Evidence from cross-listing events. International review of financial analysis. 2017; 49: 12-23.

[11] QT Luu, TH Vu. Long run outperformance of stock return following seasoned equity offerings: evidence from Vietnam stock market. International Journal of Economics, Business and Management Research. 2021; 5: 18-25.

[12] Ibbotson R. Price performance of common stock new issues. Journal of Financial Economics. 1975; 2: 235-272.

[13] Liu W. A liquidity-augmented capital asset pricing model. Journal of Financial Economics. 2006; 82: 631-671.

[14] Griffin JM, Harris JH, Topaloglu S. The dynamics of institutional and individual trading. Journal of Finance. 2003; 58: 2285-2320.

[15] Hung W. Institutional trading and attention bias. Journal of International Financial Markets, Institutions \& Money. 2014; 29: 71-91.

[16] Sias R. Institutional herding. Review of Financial Studies. 2004; 17: 165-206.

[17] Ying H, Robin KC, Keng-Yu H, Pei-Shih W. The impact of foreign institutional traders on price efficiency: Evidence from the Taiwan futures market. Pacific-Basin Finance Journal. 2015; 34: 24-42.

[18] Yong H, Konari U, Daolin Z. Market timing of seasoned equity offerings with long regulative process. Journal of Corporate Finance. 2016; 39: 278-294.

[19] Yong R, Xin S, Kai Z. Do large shareholders collude with institutional investors? Based on the data of the private placement of listed companies. Physica A: Statistical Mechanics and its Applications. 2018; 508: 242-253.

[20] Wermers R. Mutual fund herding and the impact on stock price. Journal of Finance. 1999; 54: 581-622.

[21] Zhijuan C, William TL, Changfeng M, Shih-Chuan T. Liquidity provisions by individual investor trading prior to dividend announcements: Evidence from Taiwan. North American Journal of Economics and Finance. 2014; 28: 358-374. 